using the method of free (facilitated) discussion. methodological guide. Comp. I. V. Ievleva, M. V. Potapova]. Polytechnic University, Saint Petersburg (2016).

28. Muzey i shkola v obrazovatel'nom prostranstve. Vypusk 2: "Obraz i mysl". Sb. Statey [Museum and school in the educational space. Issue 2: "Image and thought" Collection of articles]. Saint Petersburg (1997).

DOI 10.15826/B978-5-7996-3081-2.52

\title{
Multimedia Practices in Corporate Museums: Tribute to Fashion or Canon Transformation
}

\section{Pryamikova Elena ${ }^{1}$, Vandyshev Mikhail ${ }^{2}$}

1 Ural State Pedagogical University, Ekaterinburg, Russian Federation

${ }^{2}$ Ural Federal University, Ekaterinburg, Russian Federation

Corresponding author: Pryamikova Elena, pryamikova@yandex.ru

\begin{abstract}
In the framework of the project "Scaling social memory of generations in 'historically' and 'newly' industrialized cities" we have studied various organizations associated with commemoration work. We have interviewed people and have had excursions in various museums: school museums, town museums, local history museums, and corporate museums. All in all, we have visited 11 corporate museums in several cities of Ural region. Certainly, now the best equipped museums are corporate museums of economically booming plants. They are supplied with state-of-the-art equipment that allows them to create fundamentally new expositions, change the traditional canon of the exhibition and storage of museum collections. Nevertheless, not all corporate museums follow this route, there are some which maintain traditional practices of housing exhibits. How do corporate museums of towns and cities of the Ural region work today? How would museum staff like to change their work with regard to use of multimedia technologies?
\end{abstract}

Keywords: corporate museums, identity, multimedia equipment, multimedia practices, Ural region 


\section{Introduction}

A big city museum, especially the one situated in the tourist area, has its audience and, as a consequence, has resources for development. A smalltown museum often has limited resources, its audience is small and not very attached to it. Nevertheless, both museums are strategic centers of commemoration.

In our project, we have studied museums of three types: local history museums, museums of enterprises, and museums of educational establishments. The theory of multi-scalar scaling seems specifically relevant to apprehend and classify them. In small towns all museums are technically local, however some local history museums can go beyond the settlement and present a wider history of the region, corporate museums tell not only about the enterprise of the town, but about the lead plant (holdings, groups of companies, etc.), and museums of educational establishments tell not only their own history, biographies of their graduates, but also tell about different historic periods of their life (in our case, this is mostly the soviet period).

We have interviewed people and have had excursions in various museums: school museums, town museums, local history museums, and corporate museums. All in all, we have visited over 50 museums in several towns of the Ural region and 11 of them were corporate museums. Activities of corporate museums have their specific features. At the same time, they may resonate with the town museum activities, many of our informants talked about their cooperation with other museums of the town. On the web site of the museum and exhibition center of PAO 'Uralkali' you can read the following, "It's a reflection of the company's history through men's destinies, through unique production, household, and antique exhibit items, through the use of the state-of-the-art technologies". On the same web site there is a poster of the exhibition 'Glimpses of the War-Time Childhood'. This is an art exhibition of Rosalia Shcherbinina, a veteran of 'Uralkali', a painter from Berezniki and a stonecutter, dedicated to the $75^{\text {th }}$ Anniversary of the Victory. A main objective of corporate museums is presentation, the demonstration of the advantages of an enterprise itself. It is a museum that welcomes guests to the enterprise and a visit to the museum is mandatory for new employees. And certainly schoolchildren often visit such museums.

* Web site of the museum and exhibition center of PAO 'Uralkali'. Access mode: https://www.museum.uralkali.com/ 
Thus, the museum plays the role of a carrier guidance. That is why the main characters of such museums are honored employees of the enterprise. Our paper is dedicated to the activities of corporate museums in towns and cities of the Ural area. How would museum staff like to change their work with regard to new technologies?

Certainly, now the best equipped museums are corporate museums of economically booming plants. They are supplied with the state-of-the-art equipment that allows them to create fundamentally new expositions, change the traditional canon of exhibitions and storage of museum collections. Not all corporate museums follow this way, there are some of them which maintain traditional practices of showcases with exhibited items, boards with photos and comments on them. In our interviews, we also asked what the staff would change in their museum, if they had all the necessary resources.

\section{Objectives of Corporate Museums. Town History is History of an Enterprise}

A concept of a museum and its exhibition activities is based on a) the specifics of a town and request for designing the town identity (culture); b) regional specifics based on local history (enthusiastic researchers of their home area); c) an historic period with a significant series of events; d) interests of museum visitors of different generations, and e) local industry, including educational establishments, production enterprises, etc. Collectively such a constellation of concepts should actually be a memory storage and exhibition place but museums have their different ways to intertwine with the space of small industrial towns.

Sh. Zukin remarks in his works that in big cities, as a result of gentrification, there is a rising interest in various kinds of heritage [Zukin, 2019] and in this connection museums turn from 'larders' into drivers of economic growth based on a generation of new senses and flows of visitors. How true is it for a small town and a city? For the moment, the primary consumers of museum products in small towns are schoolchildren. The objective of such museums is to create and transfer canons of memory, ensure the identity of a town, a plant, a region and even a nation.

Can a corporate museum of a small town create a narrative of authenticity of a place and thus attract a varied audience? According to Zukin, authenticity is a "cultural form of governance of a certain territory", a "cultural right to reserve for the good and all the home for all people, who live and 
work in the town" [Zukin, 2019, 16]. The corporate museum is an integral part of the authentic town space of a small Ural town. Expositions show the history of industrialization, transformation of a town, construction of plants, hard work and survival during war, and the changes in the 1990s, when many plants stopped manufacturing. This is the history of a town told by corporate museums. "... first of all, the territory, where you live, is a history of the enterprise... the history of the town is the history of the enterprise. That is why you need to know the history of the enterprise in order to understand what the enterprise manufactured. We had some situations when children came from the other part of the town and there was a question - What does the plant manufacture? Even the name of our plant didn't show them that it manufactured paper. They could say anything, but not what it actually manufactured" (interview, museum of Solikamskbumprom).

The unique character of the museum is highlighted not only with the contribution the plant made in the development of the town. The museum of the light railroad in Alapayevsk can justifiably count itself the most unique museum, the longest light railroad is still in operation there and it is used by tourists who visit Verkhnya Sinyachikha as well as transports everything necessary for living to a number of settlements.

The museum of VSMPO-AVISMA corporation includes two main parts. "So, there is a historical part, as we call it, and that is our history. There is the history of manufacturing, the history of people who worked here, etc. It was always like this in the Soviet times. It is partly true now. And also the technical part. This is our manufacturing, our equipment, our products, our, so to say, the main components, that we manufacture" (interview, museum of VSMPO-AVISMA Corporation).

The first part of the museum ensures authenticity of the plant and the town, highlights their unity. The museum of the corporation that manufactures semi-manufactured products from titanium for the aircraft industry is decorated accordingly. "...we have decided to add some theatre and make the entry zone in the form of a cabin of an aircraft. We can see windows here. To the right there is the past, the pretty faraway past, in terms of the Ural plants... We are not Demidov's plant, but still. The beginning of the 1930s, Verkhnya Salda, the view from the bell tower. And the plant... the beginning of the 1950s. There were potato fields, private housing. So we have decided like this. On the opposite side you can see the modern town and modern plant through the windows" (interview, museum of VSMPO-AVISMA Corporation). 
The museum is not just a demonstration of expositions; it is a restoration, reconstruction of past events. "It is commemoration work, it is history. I tell you... there are about 12 books on different topics, including war and on specific chapters of history of the plant. It was done with the help of our management" (interview, museum of VSMPO-AVISMA Corporation). The historical part covers an episode from the 1990s, how they solved the problem of survival. "The first signing of the contract of a strategic partnership with Boeing. Tetukhin signs. And Mr Fradkov. he wasn't even the prime minister at the time. He was a minister of foreign economic relations. $<\ldots>$ And in 2009 a joint venture with Boeing was set up here in Verkhnya Salda. Cooperation with Boeing in general, here is the ribbon and the pen they used to sign the contract. Here's the pen". "So, this titanium suitcase or a case, as you wish, was manufactured in one night, it's completely made of titanium. The case, the handles, the wheels - everything is made of titanium. Our managers of the foreign economic department 'travelled' with this case and offered our product". (interview, museum of VSMPO-AVISMA Corporation).

The corporate museum exhibition is refilled mostly due to veterans and employees. It may be one of the functions of the museum to collect information about labor dynasties, "in cooperation with the council of veterans and the museum we started collecting this information. We also did it through our corporate newsletter called 'Bumazhnik'. We published information for the veterans of our plant and for the employees, so that people would feel free to come and talk about their dynasty" (interview, museum of Solikamskbumprom). We can say that in the historical part of corporate museums there prevail practices that originated from the USSR, they highlight the heroism of soldiers and war workers, pay tribute to veteran employees of the plant. They demonstrate the achievements of industrialization, and how the plant transformed the town.

The modern component is a display of products, characteristic features of production, which in addition to a presentation function plays an important role of occupational guidance, to catch the interest of children and teenagers in the plant and provide the flow of workers and specialists in future.

\section{Use of Multimedia Equipment in Corporate Museums}

Multimedia equipment can be installed in a local history museum, it can practically never be found in a school museum, but most often such innovations can be seen in corporate museums. The functional tasks of corporate 
museums differ from school and town museum. The task of a corporate museum is to show the history of an enterprise and its present. Multimedia serves as an indicator of well-being of the enterprise that can afford such luxury as a roaring dinosaur or an acting model of mining equipment.

There are several reasons to use multimedia equipment in a museum. Firstly, it helps to present widely exposition and exhibition material, an alluring image stays with the audience. Secondly, information services improve, with audio guides replacing traditional excursion stories. The staff have more time to organize face-to-face meetings with visitors who want to know more about the work of the museum. Thirdly, information computer stands help visitors to study audio/video files with historical reference resources about various collections of the museum, which are permanently redeveloped [Mysheva, 2015]. Another important addition to the opportunities provided by multimedia equipment is the atmosphere it creates in the halls of a museum, listening to pieces of music, watching old documentary films.

The following information can be found on the web site of Magnezit Group: "due to implementation of the project 'From Museum of the Plant to Museum of Knowledge' that received a grant of the XIIth contest 'Changing Museum in Changing World' of the Charity Fund named after V. Potanin, traditional historical and cultural institutions are transformed into modern educational and occupation guidance centers"* The director of the center is proud to speak about the transformed space of the museum. "Transformer-museum, mobile museum, interactive museum. It's a small space, but we tried to make it multifunctional $\langle\ldots\rangle$ Now it's a cinema and lecture hall, in 20 minutes it can be a workshop hall, a meeting room, a room for some other activities, etc." (interview, the museum of Magnezit Group, Satka). Indeed, furniture in the museum is convertible, convertible chairs in the interactive hall can be transformed into benches or cabinet cases for exhibiting. ${ }^{* *}$ There are drawers that you can pull out and discover amazing contents, the idea is to make it fun for a visitor to discover what is there in the next cabinet case or drawer.

Certainly, such things are meant first of all for children, since they feel awkward in a traditional museum where it is forbidden to touch everything.

In Satka they prepare to open modernized museum of 'Magnezit' // Source - web site of Magnezit Group. Access mode: http://magnezit.ru/ru/about/press/news/?id4=1002

Renovation project of the museum 'Magnezit' is prepared by the architect bureau 'KONTORA' (Moscow), designer Dmitry Baryudin 
When many things are accessible to study, when you can hold pieces of ore in your hands, open many drawers, children show more interest in exploring such a space. "Children like bright things", says the director. Catching the interest of children and teenagers who came for the excursion, launch the mechanism of generation of local identity with the town and the plant is a clear idea that helps to implement the occupational guidance function of museum.

Nevertheless, such experiments are debatable in the museum community. Digital presentations relate differently to museum expositions. They can:

- illustrate materials and facilitate understanding;

- complement the main exhibition and create a special atmosphere in each hall;

- bring in game and entertainment elements [Lebedev, 2007].

Not many employees of museums and specialists in this field would like to change the traditional canon of museum activity: “...this memory typewriter called a computer, alas, has given us and museum craft almost nothing, but speed, and, therefore, nervous behavior of a know-all and a fussy dullness of shallowness Moreover, global computer applications have aggravated the museum paradox and the paradox about museums: for two centuries the museum, the storage of the original, promoted itself with reproduction. Digital now" [Vdovin, 2007, 40].

Understanding the museum as a sanctuary, as a storage of unique documents and objects stands against such changes. The interest that an object arouses is replaced with its digital image though woven into a wider and clearer picture that enhances the importance of the object itself. Such presentation distracts attention from core value, the object itself!

There is another point of view that a museum and things are a basis for a cult of rare things, a competition between museums. Thus, the latter turn into seekers of values and the advantage of a museum appears in its cost, in the amount its exhibition items cost. Development of the digital environment of museums will probably change this situation drastically in the future. "On the one hand, global, omnivorous, insatiable museumification marks the total triumph of thingness. On the other hand, an amazing progress of ethereal electromagnetic flows freely floting in the air, in human feeling in tune with the archetypical model of all advanced religious confessions, steadily testifies that the vector of the earth's evolution is programmed to the forthcoming dematerialization". [Drikker and Makoveckij, 2016, 35] 
In this discussion, corporate museums take a special place; very often the objects exhibited there are of value for the enterprise and the people who worked or who are still working there. On the web site of the Magnezit Group museum we can read, "we have made an emphasis not on mechanisms or production processes as they used to be, but on the plant's core value that is the people who made it possible that 'Magnezit' became and still is a leader of the refractory industry of the country. We hope that the new museum will allow enhancing prestige of production and professions in demand, demonstrating the most important role of the state-of-the-art technologies and education"*

The museum of PAO 'Uralkali' in its advertisement offers 5 exhibitions, two of them are associated with the $75^{\text {th }}$ Anniversary of the Victory, these are 'Glimpses of the War-Time Childhood' and 'Battle-Field Album' - an exhibition of retro photos of the Great Patriotic War. Another exhibition called 'Enchanted Minerals' is an exhibition of minerals from the private collection of Tamara and Alexander Dupin, veterans of Uralkali and geologists. Another completely interactive exhibition called 'Following the Path of Discoveries and Challenges' is dedicated to the $95^{\text {th }}$ anniversary of the Verkhekamskoye salt deposit. And the last one called 'New Year Hand Made' is an exhibition of creative works of Uralkali employees from the series 'World of Hobbies. "It's a reflection of the company's history through the lives of people, through unique exhibit items of production, household, and antiques, through the use of the state-of-the-art technologies", we read on the web site of the museum. ${ }^{* *}$

Emphasis on the activities of people, on the history of the enterprise, leads to the fact that such different museums as PAO 'Uralkali' and 'VSMPO-AVISMA' mostly hold to the traditional canon of an exhibition, reconstructing the history of the plant and its present, despite differences in equipment. The museum of 'VSMPO-AVISMA' does not have such abundant technological infrastructure as the museum of PAO 'Uralkali' does. Besides the roaring dinosaur, we can see an operation of the complex 'Ural', the process of salt production. An interactive exhibition can help to demonstrate equipment's operations. Still, many museums focus on making models that show components and the operation of actual equipment.

In Satka they prepare to open the modernized museum of 'Magnezit' //Source - web site of Magnezit Group. Access mode: http://magnezit.ru/ru/about/press/news/?id4=1002

** Web site of museum PAO 'Uralkali' https://www.museum.uralkali.com/berezniki-events

${ }^{* * *}$ Web site of museum PAO 'Uralkali' https://www.museum.uralkali.com/ 
The museum of the paper-making plant 'Solikamskbumprom' is decorated in the 'old photo album' style." The whole history of the plant is presented on high-quality boards, there are a lot of photos and copies of documents. New employees come to the museum and bring their children. Such a format is good for veterans. "...I thought we are not that modern and probably this is our disadvantage, but it turned out that it's a great advantage due to faceto-face communication, and these photos. $<\ldots>$ So there was positive feedback as well $<\ldots>$ That's why I said that I would have left this part as it is to have this face-to-face communication and put our veterans in this atmosphere" (interview, museum of $\mathrm{AO}$ "Solikamskbumprom").

When we asked how the museum might change if there were all the necessary resources, they answered that they would have made models for children to illustrate key points of manufacturing. "I wouldn't change anything here, but if we were allowed to expand our territory, I would have organized some activities for children. Something modern to arouse children's interest. I would like these models to operate, work $<\ldots>$ Then, children will show more interest in paper making. We need to surprise them by newsprint production. They are kept out of the industrial site, only students and graduates can go there. As an occupational guidance. Younger children are kept out. It's very difficult to tell them about newsprint production and it is shown only in photos". (interview, museum of AO "Solikamskbumprom").

\section{Results and Discussions. Types of Corporate Museums}

Based on a museums' interest in attracting both future employees and consumers, they become a kind of exhibition center that demonstrates the capabilities of a plant and offers fine content to their visitors. In this respect, the museum of Magnezit Group is outstanding with its creative approach to organizing its work. The magnetism of a museum, its capability to attract an audience depends on various agents that expand the memory space of their national and sociocultural community. In Satka, a town of international street art, which is not afraid of experiments, such an interactive museum, a transformer-museum, blends seamlessly with the environment.

The museum of PAO 'Uralkali', despite all its technical capabilities, still holds to the traditional canon, the most important thing is people, their

* One of the names from the classification of N. V. Veselkova, Candidate of Social Sciences, participant of the research project. 
memories, personal belongings that reflect the events of the past. Multimedia equipment in this case is more of a tribute to fashion, an indicator of economic well-being of the enterprise. The history of the plant and history of the town are bounded together, and evidence of this unity are shown in glass showcases. However, the museum of 'VSMPO-AVISMA' demonstrates rare and unique exhibit items, such as the first titanium ingot or a titanium case, which helped to secure the future of the enterprise. Old railroad trains, diesel-powered locomotives and other machinery of the Alapayevsk light railroad are no less unique. There is an old locomotive TU2 at the entrance checkpoint resting on a plinth to celebrate the $90^{\text {th }}$ anniversary of the Alapayevsk light railroad in 1988.

These exhibit items are of value for the employees of the plant, especially veterans, because they have spent most of their life next to these things. Such exhibit items can also be of interest for schoolchildren. The question is will they help in the formation of identity with the town, will they ensure the authenticity of the place - the town and the enterprise?

\section{Conclusions}

The concept of a corporate museum, its exhibition activity today, rests mostly on the specifics of an enterprise and a town, at least the museum endeavors to design a joint identity of a town-plant in the past, present, and preferably in future. A corporate museum also takes into consideration regional specifics from the point of view of manufacturing. In Zlatoust one may hear many stories about the invention of damask steel. Visitors of this museum are told that in this city in the beginning of the $19^{\text {th }}$ century Pavel Anosov recreated the lost technology of the legendary steelmaking. Corporate museums show all characteristic features of the historic period of industrialization, if a town is new, and, in addition, specifics of arts and crafts, if a town has a longer history. Corporate museums endeavor to meet the interests of consumers of museum memory of different generations. Today the museum of AO 'Solikamskbumprom' as an 'old photo album' is more attractive for veterans, employees who were a part of labor dynasties, and people, who can come and see moving moments of the past, look through old photos. Technical innovations, multimedia equipment and models demonstrating operations of the manufacturing equipment are meant for the plant product consumers and young generation as future employees and specialists. 
In our view, the importance of multimedia practices in museum activities depends not only on the capabilities of the enterprise to equip the museum or on the museum management's wish to make applications and get grants for its development. It depends on the canon, traditional practices of the museum focused on certain consumers of the museum's work. Multimedia equipment can help to demonstrate in a more fascinating way some episodes from the past, creating a special atmosphere, but it distracts attention from the important things, from the exhibit item itself, from the thing, from the actual evidence of the past, from something that is meant to arouse admiration and respect in accordance with the museum canon.

\section{Conflict of Interest}

The authors have no conflict of interest to declare.

\section{Acknowledgment(s)}

The research project "Scaling social memory of generations in the cites of "old' and "new" industriality" is supported by the Russian Foundation for Basic Research, № 18-011-00456. Years of implementation - 2018-2020.

\section{References:}

1. S.H. Zukin. Obnazhennyj gorod. Smert' i zhizn' autentichnyh gorodskih prostranstv [The Naked City. The death and life of authentic urban spaces]. Izd-vo Instituta Gajdara [Gaidar Institute Publishing House] Moscow (2019).

2. T. P. Mysheva. Mul'timedia v muzejnom prostranstve. Mediaobrazovanie. [Multimedia in the museum space. Media Education]. № 3 (2015). Pp. 65-71.

3. A. Lebedev. Informacionnye tekhnologii i sovremennaya muzejnaya ekspoziciya [Information technology and modern museum exposition]. Rossijskoe ekspertnoe obozrenie [Russian expert review]. № 6 (23) (2007). Pp. 30-35.

4. G. Vdovin. Pamyati muzejnyh illyuzij ili paradoks o muzee dvadcat' let spustya [In memory of Museum illusions or the Museum paradox twenty years later]. Rossijskoe ekspertnoe obozrenie [Russian expert review]. № 6 (23) (2007). Pp. 39-41.

5. A.S. Drikker, E. A. Makoveckij. Muzejnyj hram [The Museum temple]. Mezhdunarodnyj zhurnal issledovanij kul'tury [International journal of cultural research]. № 3 (24) (2016). Pp. 25-36. 